\title{
PENGARUH MODEL PEMBELAJARAN KOOPERATIF TIPE PREDICTION GUIDE TERHADAP KEMAMPUAN MENULIS PANTUN OLEH SISWA KELAS VII SMP SWASTA RIS MADUMA TANJUNG BERINGIN
}

\author{
Mailani Lumbangaol ${ }^{1}$, Berman Hutahaean ${ }^{2}$ \\ *1. Penulis \\ *2. Pembimbing \\ Program Studi Pendidikan Bahasa Indonesia, Fakultas Keguruan dan Ilmu Pendidikan, Universitas Katolik \\ Santo Thomas, Jl. Setia Budi No. 479-F Tanjung Sari Medan - Kode Pos No. 20132, email- \\ mailanigaol@gmail.com
}

\begin{abstract}
Abstrak
Penelitian ini bertujuan untuk mengetahui pengaruh penggunaan model pembelajaran Kooperatif tipe PredictionGuide terhadap kemampuan menulis pantun. Penelitian ini dilakukan di SMP Swasta Ris Maduma Tanjung Beringin, pada tahun pembelajaran 20162017. Model yang digunakan dalam penelitian ini adalah model eksperimen dengandesain static group comparationSampel penelitian ini adalah semua siswa kelas VII SMP Swasta Ris Maduma Tanjung Beringin yang terdiri dari 2 kelas yang berjumlah 55 siswa, 27 siswa sebagai kelas kontrol yang diajar dengan pembelajaran langsung tanpa menggunakan model pembelajaran dan 28 siswa sebagai kelas eksperimen yang diajar dengan menggunakan model pembelajaran Kooperatif tipe Prediction Guide.Instrument yang digunakan dalam pengumpulan data adalah test-essay dalam bentuk penugasan, yaitu menulis pantun. Pengujian hipotesis dilakukan dengan menggunakan uji “" $t$ ”.

Temuan dalam penelitian ini menunjukkan bahwa kemampuan siswa dalam menulis pantun tanpa menggunakan model pembelajaran termasuk dalam kategori cukup dengan nilai rata-rata 69,96, sedangkan dengan menggunakan model pembelajaran termasuk dengan kategori baik dengan nilai rata- rata 79,96. Selanjutnya pengujian hipotesis menunjukkan $\mathrm{t}_{\text {hitung }}>\mathrm{t}_{\text {tabel }}$ yaitu 3,70>1,88 pada taraf signifikan $\alpha=0,05$ atau $5 \%$ dengan demikian, terbukti bahwa hipotesis alternatif $\left(\mathrm{H}_{\mathrm{a}}\right)$ diterima dan dapat dinyatakan bahwa model pembelajaran Kooperatif tipe Prediction Guide berpengaruh terhadap kemampuan siswa dalam menulis pantun siswa kelas VII SMP swasta Ris Maduma tahun pelajaran 2016-2017. Dengan demikian model pembelajaran ini tepat digunakan dalam proses pembelajaran, khususnya dalam pembelajaran menulis pantun.
\end{abstract}

Kata Kunci: menulis pantun, model pembelajaran Kooperatif tipe Prediction Guide

\begin{abstract}
This study aims to determine the influence of cooperative learning model predicate guide to the ability to Write traditional poetry. This research was conducted in SMP Ris Maduma Tanjung Beringin, in the year 2016-2017. The model used in this research is experiment model with desaign static group comparation. Sample of this research is all student of class VII SMP Ris Maduma Tanjung Beringin which consist of 2 class which amount 55 students. 27 students as control class are taught by direct instruction without using learning model and 28 students as experiment class which is taught with cooperative learning model of prediction guide type. Instrument used in data collection is test essay in the form of assignment that is writing poetry.trieal hypothesis used with test "t".

The findings in this study indicate that the ability of students in writing poetry without using the learning model included in the category enough with an average value of 69.96


while using the model of learning to include the category of good with an average value of 79.96. Then the hypothesis testers show . $t_{\text {hitung }}>t_{\text {tabel }}$ yaitu 3,70 $>1,88$ pada taraf significan $\alpha=0,05$ atau $5 \%$ This, it is proven that alternative hypothesis is accepted and it is stated that the cooperative learning model of type prediction guide has an influence on the students' ability in writing poetry of grade VII of teaching year 2016-2017. Thus this learning model can be used in the learning process especially in writing traditional poetry.

\section{Keywords: write poetry cooperative type prediction guide}

\section{PENDAHULUAN}

Pembelajaran Bahasa dan Sastra Indonesia menitikberatkan pada empat keterampilan berbahasa, meliputi membaca, menulis, menyimak, dan berbicara yang saling berhubungan dan saling menunjang satu sama lain. Keterampilan menulis merupakan salah satu keterampilan berbahasa yang memiliki manfaat besar bagi kehidupan manusia dalam berkomunikasi secara tertulis.

Menurut Dalman (2011: 3) Menulis merupakan suatu kegiatan komunikasi berupa penyampaian pesan (informasi) secara tertulis kepada pihak lain dengan menggunakan bahasa sebagai alat atau medianya. Aktivitas menulis melibatkan beberapa unsur, yaitu: penulis sebagai penyampaian pesan, isi tulisan, saluran atau media, dan pembaca. Menurut Tarigan (2005: 21) bahwa menulis menurunkan atau melukiskan lambang-lambang grafik yang menggambarkan suatu bahasa yang dipahami seseorang sehingga orang lain dapat membaca lambanglambang grafik tersebut kalau mereka memahami bahasa dan grafik yang sama. dari segi bahasa yang digunakan penulis yang perlu diperhatikan dalam menulis.

Oleh karena itu keempat keterampilan berbahasa menulis harus lebih diperhatikan. Dalam penelitian ini difokuskan adalah kemampuan menulis pantun pada siswa kelas VII SMP Swasta Ris Maduma. Dalam Kamus Besar Bahasa Indonesia (2008: 1017) pantun adalah bentuk puisi Indonesia (Melayu), tiap bait (kuplet) biasanya terdiri atas empat baris yang bersajak (a-b-a-b), tiap larik biasanya terdiri atas empat kata, baris pertama dan baris kedua biasanya untuk tumpuan (sampiran) saja dan baris ketiga dan keempat merupakan isi. Menulis pantun di sekolah bertujuan untuk meningkatkan kemampuan dan memperluas wawasan siswa tentang sastra. Menulis pantun juga mengarahkan dan mempertajam daya pikir siswa.

Menulis pantun terdapat dalam kompetensi dasar yang ada dalam Kurikulum Tingkat Satuan Pendidikan (KTSP) yang sudah diterapkan di sekolah SMP swasta Ris Maduma pada siswa yang berada di kelas VII semester 1 di dalam silabus. Pembelajaran tentang menulis pantun sesuai dengan syarat-syaratnya terdapat dalam standar kompetensi "8. Mengekspresikan pikiran, perasaan, dan pengalaman melalui pantun". dan Kompetensi dasar, "8.1. Pada pembelajaran ini siswa diharapkan mampu menulis pantun yang sesuai dengan syarat-syarat yang telah ditentukan".

Faktor penyebab rendahnya tingkat ketuntasan belajar, 1) siswa menulis pantun menganggap menulis itu sulit, 2) kurangnya motivasi dan keterampilan menulis dan keterampilan menulis pada diri siswa, 3) banyak siswa yang mengeluh dalam menulis pantun dengan teknik konvensional 
yaitu diberi penjelasan materi yang kemudian diikuti dengan kegiatan menulis pantun di dalam kelas. Faktor guru, enggan memberikan pelajaran menulis pantun di dalam kelas. (Purnawan, Efendi \& dkk, 2014: 24). Hal ini juga senada dengan skripsi Ririn Wulandari yang berjudul "pengaruh penggunaan teknik pembelajaran ice breaker terhadap kemampuan menulis pantun siswa kelas VII Swasta Pahlawan Sukaramai tahun pelajaran 2012-2013" yang menyatakan rendahnya kemampuan siswa dalam menulis pantun disebabkan oleh beberapa faktor yaitu kurangnya kemampuan siswa dalam pembelajaran menulis pantun, masih menotonnya kegiatan belajar mengajar yang dilakukan guru, dan belum adanya teknik atau model yang tepat. Oleh karena itu, peran guru sebagai pengajar harus menguasai model pembelajaran yang praktis, efisien, kreatif dan inovatif. Siswa memiliki kemauan dan semangat yang berbeda-beda. Jadi sebagai seorang guru harus dapat membangkitkan kemauan mereka dengan memotivasi dan melakukan berbagai teknik pembelajaran yang kreatif dan inovatif dalam proses pembelajaran. Hal ini juga didukung dari hasil wawancara antara si peneliti dengan guru bahasa Indonesia yang ada di SMP Swasta Ris Maduma Tanjung Beringin yang mengatakan masih banyak siswa yang mengalami kendala seperti kurangnya kemampuan siswa dalam menulis dan memahami sampiran dan isi pantun dan kurangnya siswa tidak memahami dan mengerti dengan sajak a-b-a-b atau serta sulitnya menemukan ide atau gagasan dalam menulis pantun sehingga banyak siswa yang mendapat nilai di bawah KKM yang mana nilai KKM di sekolah tersebut 75 .

\section{KAJIAN KEPUSTAKAAN Pengertian Model Pembelajaran Prediction Guide}

Model pembelajaran Prediction Guide dikembangkan untuk menarik perhatian siswa selama mengikuti pembelajaran. Ini adalah model yangMasalah yang sering ditemui pada siswa saat menulis pantun adalah sulitnya membuat pilihan kata,ataumenuangkan ide, dan gagasan. Sehingga siswa kurang mampu menuliskan pantun dan kurangnya penggunaan pantun dijaman sekarang dalam kehidupan sehari-hari sehingga sulit

Menanggapi masalah tersebut, terdapat satu model pembelajaran kreatif dan inovatif yang cocok untuk mengatasinya. Penulis menawarkan satu model pembelajaran yang dapat digunakan dalam kegiatan pembelajaran prediction guideterhadap kemampuan menulis pantun.

Menurut Zaini (2008: 4), strategi pembelajaran aktif tipe prediction guide merupakan strategi pembelajaran secara aktif dari awal sampai akhir pembelajaran. Dalam strategi ini siswa diminta untuk menebak apa saja kirakira yang akan mereka dapatkan dalam pembelajaran nanti. Selain itu membuat siswa aktif dari awal hingga akhir pelajaran. Strategi ini juga menuntut siswa untuk memiliki keterampilan menulis pantun selama pelajaran berlangsung. Model pembelajaran Prediction Guidemerupakan metode tebak pelajaran dikembangkan untuk menarik perhatian siswa selama mengikuti pelajaran model ini adalah model yang digunakan yang melibatkan peserta didik di dalam proses pembelajaran secara aktif dari awal sampai akhir. Dengan model ini peserta didik diharapkan dapat terlibat dalam pelajaran semenjak awal pertemuan dan 
tetap mempunyai perhatian ketika

Model pembelajaran Prediction

Guide dikembangkan untuk menarik perhatian siswa selama mengikuti pembelajaran. Ini adalah model yang digunakan untuk melibatkan peserta didik di dalam proses pembelajaran secara aktif dari awal hingga akhir.

Model ini dapat diterapkan untuk hampir semua mata pelajaran yang tidak bersifat aplikatif, seperti ilmu-ilmu eksakta. Kelas akan menjadi lebih dinamis jika diadakan kompetisi antar kelompok untuk mencari kelompok dengan prediksi yang paling banyak benarnya. (Istarani, 2001: 1).

\section{Langkah-Langkah Model \\ Pembelajaran Prediction Guide}

$$
\text { Menurut Istarani }
$$

204)langkah-langkah

(2011:

Menggunakanmodel

pembelajaranPrediction Guide adalah sebagai berikut

1.Tulislah atau tayangkan melalui LCD subject matter dari pelajaran yang akan disampaikan

2.Mintalah kepada siswa untuk menuliskan kata-kata kunci apa saja yang diprediksikan muncul dari materi pembelajaran yang akan disampaikan oleh guru.

3.Sampaikan materi pembelajaran secara interaktif

4.Selama proses pembelajaran siswa diminta menandai hasil prediksi mereka yang sesuai dengan materi yang akan disampaikan oleh guru.

5. Di akhir pelajaran tanyakan beberapa tebakan mereka yang benar.

\section{Kelebihan Model Pembelajaran Prediction Guide}

Menurut Istarani (2011: 205)

kelebihan dari model pembelajaran prediction guid dapat dibedakan menjadi beberapa yakni :

1.Dapat meningkatkan motivasi belajar siswa karena pembelajaran yang dilakukan dengan menebak suatu materi ajar yang dipertanyakan.

2.Pembelajaran yang akan lebih hidup karena membuat siswa terus berpikir pengajar menyampaikan materi. mencari jawaban selama proses pembelajaran berlangsung

3.Siswa tidak cepat jenuh dan bosan dalam mengikuti proses belajar mengajar

4.Siswa lebih interaktif dalam mengikuti proses belajar mengajar.

\section{Kelemahan Model Pembelajaran Prediction Guide}

Menurut Istarani (2011: 205), kelemahan model pembelajaran dibedakan menjadi beberapa menjadi dua yakni ;

1. LCD yang tersedia kurang sesuai sebagaimana yang diharapkan

2. Ditemukannya guru kaku dalam menyampaikan materi dengan menggunakan LCD.

\section{Pengertian Menulis}

Ada beberapa pendapat para ahli tentang definisi dari menulis. Menurut Dalman (2011: 3), Menulis merupakan suatu kegiatan komunikasi berupa penyampaian pesan (informasi) secara tertulis kepada pihak lain dengan menggunakan bahasa sebagai alat atau medianya. Aktivitas menulis melibatkan beberapa unsur, yaitu : penulis sebagai penyampaian pesan, isi tulisan, saluran atau media, dan pembaca.

\section{Hakikat Pantun \\ Definisi Pantun}

Pantun merupakan salah satu jenis sastra lisan yang berbentuk puisi. Pantun dikenal di berbagai daerah di Indonesia dengan nama yang berbeda-beda. Dalam bahasa Minang, pantun berasal dari kata "Patuntun". Dalam bahasa Jawa, pantun dikenal dengan nama "Parikan" dan dalam bahasa Sunda dikenal dengan "Paparikan". Pada masyarakat Batak, pantun dikenal dengan sebutan "Umpama atau endeende",danmasyarakatTorajamenyebutnya dengan londe. Orang Aceh dan Ambon juga mengenal pantun dan menyebutnya dengan "Panton", sedangkan orang Bengkulu menyebutnya dengan "renang". Hampir setiap daerah di Indonesia mempunyai bentuk teks pantun walaupun dengan nama berbeda. Penyebaran pantun ke pelosok Nusantara menjadi bukti bahwa 
pantun merupakan salah satu sastra lama yang hidup dalam kebudayaan Indonesia, masih disukai sebagian masyarakat Indonesia, serta merupakan salah satu kekayaan budaya Indonesia yang perlu kita lestarikan (Kementrian pendidikan dan kebudayaan Republik Indonesia, 2014: 67).

\section{Ciri-Ciri Pantun}

Menurut N.S Utami (2013: 13 ) ciri-ciri pantun adalah sebagai berikut;

1. Setiap bait terdiri dari empat larik (baris)

2. Setiap suku kata tiap larik sama atauhampir sama (biasanya terdiri dari delapan sampai dua belas suku kata)

3. Berirama (bersajak) ab-ab atau aa-aa

4. Larik pertama dan kedua berupa sampiran yang biasanya tidak mempunyai hubungan mengandung maksud dan hanya diambil rimanya saja untuk mengantarkan maksud yang akan dikeluarkan).

5. Larik ketiga keempat disebut maksud (isi) pantun, yang merupakan tujuan dari pantun tersebut karena isi pantun mengandung pesan yang ingin disampaikan oleh si pemantun.

\section{Langkah-Langkah Menulis Pantun}

Menurut Eko Sugiarto (2013: 9) langkah-langkah menulis pantun dapat dibagi menjadi tiga bagian yaitu :

1. Menentukan Tema

Dalam menulis pantun, hal pertama yang harus kita lakukan adalah menentukan tema. Tema pantun ini akan berkaitan dengan jenis pantun yang akan kita tulis.

2. Mengumpulkan Kosakata

Disadari atau tidak, setiap jenis dan tema tertentu dalam sebuah pantuntentu akan punya kecenderungan memakai katakata tertentu.

3. Teknik Penulisan

Setelah menentukan tema dan mengumpulkan kosakata yang Pertama, cari kata terakhir isi (baris ke 3 dan ke 4) dan sesuaikan dengan tema. Meskipun ada pantun yang bersajak aa-aa, akan lebih baik jika perpajakan pantun akan ditulis bersajak ab-ab (persamaan bunyi) ini akan menimbulkan efek irama yang unik sekaligus langsung menunjukkan bahwa pol perpajakan ini (ab-ab) adalah pola perpajakan sebuah pantun. Kedua, buat kalimat-kalimat dengan kata-kata tersebut. Lakukan seperti menyusun kalimat biasa. Namun kali ini harus memperhatikan syarat pantun (terdiri dari 8-12 suku kata). Ketiga, cari kata terakhir sampiran (baris pertama dan kedua ) kata tersebut menjadi kata terakhir dalam kalimat yang kita buat. Sesuai dengan perpajakan sebuah pantun (ab-ab), syarat mutlak untuk kedua kata tersebut adalah harus sesuai persajakannya dengan kata terakhir baris ke-3 dan ke-4. Kata terakhir baris pertama mengacu kepada kata terakhir ke-3, sedangkan kata terakhir baris kedua harus mengacu kepada kata terakhir baris ke-4

\section{Hasil Penelitian yang Relevan}

Hasil penelitian yang relevan dengan penelitian tentang ketrampilan berbicara dengan berbagai model, strategi, metode yang dilakukan oleh peneliti sebelumnya yaitu:

1. Gini Warti (2014) Berdasarkan hasil uji tes-t didapat $\mathrm{t} 0=3,3082$ yang lebih besar dari table baik pada taraf signifikan $5 \%$ maupun $1 \%$ yaitu 2,00 dan 2,65. Dapat disimpulkan bahwa terdapat perbedaan hasil belajar matematika antara siswa yang mengikuti pembelajaran kooperatif tipe prediction guide dengan siswa yang mengikuti pembelajaran konvensional pada siswa kelas VII SMP Muhammadiyah Bagansiapi Api.

2. Sry Handayani (2013) Berdasarkan Keterampilan Berpikir Kritis Dan Motivasi Belajar Siswa". hasil penelitian antara lain: (1) Model pembelajaran reciprocal teaching lebih efektif dibandingkan dengan model pembelajaran prediction guide berdasarkan keterampilan berpikir kritis (uji t terhadap rata-rata skor keterampilan berpikir kritis diperoleh output $0,002<\quad \alpha$ ); (2) Modelpembelajaran Reciprocal 
Teaching tidak lebih efektif dibandingkan dengan model pembelajaran Prediction Guide berdasarkan motivasi belajar siswa (Uji t terhadap rata-rata skor motivasi belajar setelah treatmentdiperoleh output $\quad 0,4095>\alpha$ );

Keterlaksanaan model pembelajaran Reciprocal Teaching dikategorikan baik dengan persentase keterlaksanaan sebesar $77,46 \%$ dan keterlaksanaan model pembelajaran Prediction Guide dikategorikan sangat baik dengan persentase keterlaksanaan sebesar 90,35\%.

3. Evarina Eka Puspitasari (2014) Hasil yang didapat dari penelitian Erviana Eka Puspitasari, dkk (2014) keterampilan berpikir siswa sebanyak $75 \%$ pada pra siklus menjadi $81 \%$ pada siklus I menjadi $82 \%$ pada siklus II. Berdasarkan data hasil observasi keterampilan berpikir kritis siswa diperoleh persentase rata-rata $53 \%$ pada pra siklus, meningkat menjadi $68 \%$ pada siklus I meningkat lagi menjadi $70 \%$ pada siklus II prestasi belajar peserta didik juga mengalami peningkatan, dari nilai rata-rata 70 menjadi 92 pada siklus I menjadi 93 pada siklus II.

\section{METODELOGI PENELITIAN}

Penelitian ini dilakukan di SMP Swasta Ris Maduma Tanjung Beringin tahun pelajaran 2017-2018 yang berjumlah 55 orang.Metode yang digunakan dalam penelitian ini adalah metode eksperimen. Desain penelitian eksperimen ini adalah Static Group Comparison, di dalamdesain ini data kelompok dibagi menjadi dua kelompok.Rumus yang digunakan adalah uji " $\mathrm{t}$ " sebagai berikut:

$t_{o}=\frac{M_{1}-M_{2}}{S E_{M 1-M 2}}$

\section{HASIL PENELITIAN DAN PEMBAHASAN Hasil Penelitian}

Berdasarkan hasil penelitian, maka diperoleh temuan penelitian sebagai berikut:

1. Kemampuan siswa dalam menulis pantun dengan menggunakan model pembelajaran Kooperatif tipe Prediction Guide menunjukkan nilai rata-rata 79,96 termasuk dalam kategori baik.

2. Kemampuan siswa dalam menulis pantun tanpa menggunakan model pembelajaran Kooperatif tipe Prediction Guide menunjukkan nilai rata-rata 69,96 termasuk dalam kategori cukup.

3. Berdasarkan perhitungan dengan uji " $t$ " diperoleh nilai $t_{0}=3,70$ kemudian dikonsultasikan dengan tabel $\mathrm{t}$ pada taraf signifikan $0,5 \%$ dengan $\mathrm{dk} 28$ adalah 1,88. Oleh karena $t_{0}$ yang diperoleh lebih besar dari $t_{\text {tabel }}$ yaitu $3,70>1,88$ maka hipotesis nihil $\left(\mathrm{H}_{0}\right)$ ditolak dan hipotesis alternatif $\left(\mathrm{H}_{\mathrm{a}}\right)$ diterima. Hal ini membuktikan bahwa model pembelajaran Kooperatif Tipe Prediction Guide berpengaruh dengan menggunakan model pembelajaran Kooperatif tipe Prediction Guide pada siswa kelas VII SMP Swasta Ris Maduma Tanjung Beringin.

\section{SIMPULAN, IMPLIKASI DAN SARAN Simpulan}

Berdasarkan hasil penelitian yang telah diuraikan pada bab sebelumnya dan sesuai masalah penelitian in, dapat disimpulkan beberapa hal sebagai berikut:

1. Kemampuan menulis pantun pada kelas kontrol terbagi dalam lima kategori, yaitu sangat baik sebanyak 2 orang atau 7,41\%, kategori baik sebanyak 9 orang atau 33,33\%, kategori cukup baik sebanyak 14 orang atau 51,85\%, dan tidak baik sebanyak 0 orang atau $0 \%$ dengan nilai rata-rata 69,96 dan termasuk dalam kategori cukup.

2. Kemampuan menulis pantun pada kelas eksperimen terbagi dalam lima kategori, yaitu kategori sangat baik sebanyak 12 orang atau $42,86 \%$, 
kategori baik sebanyak 11 orang atau $39,29 \%$, kategori cukup baik sebanyak 3 orang atau $10,71 \%$, kategori kurang sebanyak 2 orang atau $7,14 \%$, dan kategori tidak baik sebanyak 0 orang atau $0 \%$ dengan nilai rata-rata 79,96 termasuk dalam kategori baik.

3. Dari hasil penelitian pada bab sebelumnya bahwa model Kooperatif Tipe Prediction Guide berpengaruh signifikan terhadap kemampuan menulis pantun. Hal ini dapat dilihat dari hasil rata-rata belajar siswa tanpa menggunakan model pembelajaran Kooperatif tipe Prediction Guide sebesar 69,96, standar deviasi sebesar 9,43 dan hasil rata-rata belajar siswa dengan menggunakan model pembelajaran Kooperatif tipe Prediction Guide adalah sebesar 79,96 dan standar deviasi sebesar 10,31. Kemudian dibuktikan dari hasil pengujian hipotesis dengan $t_{0}=3,70$ dan $\mathrm{t}_{\text {tabel }}=1,88\left(\mathrm{t}_{0}>\mathrm{t}_{\text {tabel })}\right.$ yang berarti $\mathrm{H}_{\mathrm{a}}$ diterima dan $\mathrm{H}_{0}$ ditolak. Hal ini membuktikan bahwa model pembelajaran Kooperatif tipe Prediction Guide berpengaruh positif dalam meningkatkan kemampuan siswa dalam menulis pantun kelas VII SMP Swasta Ris Maduma Tanjung Beringin Tahun Pelajaran 2016/2017.

\section{Implikasi}

Hasil penelitian ini memberikan implikasi secara teoretis maupun praktis, adapun Implikasinya yaitu sebagai berikut:

1. Implikasi Teoretis

Temuan peneliti ini memberikan bukti secara ilmiah bahwa model pembelajaran Kooperatif tipe Prediction Guide berpengaruh signifikan terhadap kemampuan menulis pantun. Temuan penelitian ini juga memberikan bukti bahwa dengan model pembelajaran Kooperatif tipe Prediction Guide dapat digunakan sebagai dasar untuk mengembangkan kreativitas dan ide pokok pikiran siswa dalam menulis pantun.

2. Implikasi Praktis a) Implikasi penelitian ini terhadap siswa yaitu, penelitian ini menunjukkan bahwa pembelajaran menulis pantun dengan menggunakan model pembelajaran Prediction Guide berpengaruh dalam mengembangkan kreativitas dan ide pokok.

b) Implikasi penelitian ini terhadap guru yaitu, jika guru ingin hasil yang sesuai dengan penelitian ini maka guru dapat menggunakan model pembelajaran Kooperatif tipe Prediction Guide karena model pembelajaran Prediction Guide ini mampu mengembangkan kreativitas dan menuliskan ide pokok siswa dalam menuliskan pantun. Dalam model pembelajaran Prediction Guide siswa diharapkan mampu menulis apa yang mereka pikirkan kemudian menuliskan pantun yang sesuai dengan syarat-syarat pantun dengan sebaik mungkin.

c) Implikasi penelitian ini terhadap pembaca yaitu, dengan membaca hasil dari penelitian ini pembaca dapat menerapkan atau memodifikasi pembelajaran lain dengan model pembelajaran Prediction Guide pada pembelajaran menulis pantun.

d) Implikasi penelitian ini terhadap peneliti yaitu, hasil penelitian ini menunjukkan pengaruh yang signifikan terhadap kemampuan menulis pantun, dengan demikian peneliti mendapatkan wawasan baru tentang model pembelajaran Prediction Guide.

\section{Keterbatasan Penelitian}

Dalam penelitian yang dilaksanakan, terdapat keterbatasan penelitian yang dialami penulis, yaitu sebagai berikut:

1. Keterbatasan waktu dalam penelitian, sehingga perlakuan yang diberikan kepada siswa hanya sekali pertemuan.

2. Kurang perhatian dan keaktifan siswa terhadap materi pembelajaran yang sedang berlangsung sehingga waktu yang diperlukan harus lebih banyak lagi. Namun, hal demikian tidak 
menjadi hambatan bagi peneliti dalam proses penelitian, sehingga yang dilakukan dapat berjalan dengan baik.

\section{Saran}

Berdasarkan pembahasan dan simpulan dari hasil penelitian di atas, maka pelatih memberikan beberapa saran yaitu:

1. Kemampuan siswa dalam pembelajaran menulis pantun perlu ditingkatkan dengan menggunakan model pembelajaran yang lebih efektif, karena dengan model pembelajaran siswa lebih cepat menguasai materi ajar dan siswa lebih aktif. Salah satu model pembelajaran yang dapat digunakan adalah model pembelajaran Prediction Guide

2. Guru Bahasa Indonesia hendaknya dapat menggunakan model pembelajaran yang bernilai efektif sesuai dengan materi pelajaran yang disampaikan, sehingga siswa merasa tidak dibebani oleh model-model yang menyebabkan ia merasa jenuh dan bosan ketika mengikuti kegiatan pembelajaran.

3. Perlu dilakukan penelitian lanjut oleh peneliti lane, guna memberikan masukan yang membangun bagi dunia pendidikan khususnya dalam meningkatkan kemampuan menulis pantun.

4. Siswa disarankan agar lebih efektif mengikuti kegiatan pembelajaran yang selama ini dilaksanakan serta lebih aktif sehingga akan menambah wawasan dan ilmu pengetahuan.

5. Kepala sekolah sebagai pimpinan agar lebih memperhatikan guru, siswa serta sarana dan system pengajaran guna meningkatkan mutu pengajaran khususnya bidang mata pelajaran bahasa dan sastra Indonesia.

DAFTAR KEPUSTAKAAN

Arikunto, Suharsimi 2013. Prosedur Penelitian: Suatu Pendekatan Praktik. Jakarta: Rineka Cipta.
Azwar, Saifuddin. 2013. Metode Penelitian. Yogyakarta: Pustaka Pelajar.

Dalman, 2014. Keterampilan Menulis. Jakarta: Rajawali pers.

Handayani, Sri. 2013. Efektivitas Model Pembelajaran Prediction Guide Dan Reciprocal Teaching Berdasarkan Keterampilan Berpikir Kritis Dan Motivasi Belajar Siswa. Jurnal Universitas Islam Negeri Sunan Kalijaga. http://uin-suska.ac.id.

Hadiyanto, 2001. Membudayakan Kebiasaan Menulis. Jakarta: PT. Fikahati Aneska.

Huda, Miftahul. 2014. Model-Model Pengajaran Dan

Pembelajaran; Isu-Isu Metodis Dan Paradigmatis. Yogyakarta: Pustaka pelajar.

Istarani, 2012. 58 Model Pembelajaran Inovatif. Medan: Media Persada.

Kementrian Pendidikan dan Kebudayaan, 2014. Bahasa Indonesia Ekspresi Diri Dan akademik..Jakarta:

Kemendikbud.

Nadjua, A.S. 2010. Buku Pintar Puisi Pantun. Jakarta: Triani Media Surabaya.

Priyatna, Eristika. 2014. Pengaruh Model Pembelajaran Kooperatif Tipe Prediction Guide Terhadap Pemahaman Konsep Matematika Siswa Kelas $X$ SMA Negeri 1 Kampar Timur Kabupaten Kampar. Universitas Islam Negeri Sultan Syarif Kais Riau Pekanbaru. http://uin.suska.ac.id.

Puspitasari Eka Erviana, dkk. (2014). Peningkatan Berpikir Kritis Melalui Strategi Aktif Tipe Pembelajaran Prediction Guide (Tebak Pelajaran) Pada Siswa SMPN 25 Purworejo. Universitas Muhammadiyah Purworejo tahun 2014. http://ejournal.umpwr.ac.id 
Pusat Bahasa Departemen Pendidikan Nasional. 2008. Kamus Besar Bahasa Indonesia (Edisi Ke$I V)$. Jakarta: Gramedia Pustaka Utama.

Saddhono, Slamet. 2014. Pembelajaran Keterampilan Berbahasa Indonesia. Yogyakarta: Graha Ilmu.

Sudijono, Anas. 2011. Pengantar Statistika Pendidikan. Jakarta: PT Raja Grafindo Persada.

Sugiarto, Eko. 2013. Cara Mudah Menulis Pantun Puisi Cerpen. Yogyakarta: Khitah Publishing.

Sugiyono, 2012. Metode Penelitian Pendidikan: Pendekatan Kuantitatif, Kualitatif, Dan $R \& D$. Bandung: Alfabeta.

Sujarweni, Wiratna. 2014. Metodologi Penelitian. Yogyakarta: Pustaka Baru Pres.

Tampubolon, Saor .2014. Penelitian Tindakan Kelas. Jakarta: Erlangga.

Tarigan,Guntur 2008. Menulis. Bandung: Angkasa.

Utami,N.S. 2013. 4 PM Pintar Pantun Puisi Peribahasa \& Majas. Yogyakarta: Naafi Book Media.

Wulandari Ayu Ririn. 2013. "Pengaruh penggunaan teknik pembelajaran ice breaker terhadap kemampuan menulis pantun siswa kelas VII SMP Swasta Pahlawan Sukaramai tahun pembelajaran 2012/2013. Jurnal Univeritas Negeri Medan tahun 2013. http://jurnal.unimed.ac.id. 